\title{
Histopathological Effects of Boron on Mouse Liver
}

\author{
Efectos Histopatológicos del Boro en Hígado de Ratón
}

*Eduardo Bustos-Obregón; Ricardo Hartley Belmar \& Roberto Catriao-Gálvez

\begin{abstract}
BUSTOS-OBREGón, E.; HARTLEY, B. R. \& CATRIA-GÁLVEZ, R. Histopathological effects of boron on mouse liver. Int. J. Morphol., 26(1):155-164, 2008.
\end{abstract}

SUMMARY: Boron is a non-metal element, commonly found in Nature as borates in sedimentary rocks, charcoal, oceans and soils. In Chile, it is found in high concentrations in the drinkable water of the XV region, in Arica city, in concentrations that exceed the WHO normative. The present work evaluates the effect of boron at a dose of $12 \mathrm{mg} / \mathrm{L}$ of water (equivalent to $0.0686 \mathrm{~g}$ of boric acid) given orally for 8,42 and 49 days to 3 experimental groups of 10 mice each. Liver sections were stained with PAS-hematoxyline (to evaluate glycogen), Mallory (to identify collagen fibers) and Picrosirius red with polarizing light to classify collagen fibers. Results indicate that boron evokes diverse effects in liver. Binucleated cells were evaluated and counted and results were analyzed with the non-parametric Mann-Whitney test. Control group (8-day-old mice) had 22.9 binucleated cells per 200 hepatocytes and the boron exposed group (8-dayold mice) showed 28.5 ( $>0.05$ ). Therefore, there are not significant differences among these groups. In the 126-day-old mice, the control group had 43.9 binucleated cells per 200 hepatocytes and the boron exposed group showed 76.0, a statistically significant difference $(\mathrm{p}<0.01)$. Regarding PAS staining, intensity was classified as low, moderate or intense and analysis was done with the Chi-Square test. All control and experimental groups differed with slight statistical significance $(\mathrm{p}=0.05)$. With regard to Mallory staining, intensity was examined in two specific areas: portal triads (PTr) and central veins (CV). There were significant augments in both PTr and CV results after experimental and control groups comparison. Picrosirius red staining examined in polarized microscopy revealed that collagen III was predominant in boron treated mice, denoting collagenolysis of collagen I as toxical effect of boron. In conclusion, boron alters glycogen distribution and collagen quality and deposition in the two examined areas, whereas binucleated cells behave differently in young and adult animals.

KEY WORDS: Boron; Mouse liver; Glycogen Deposition; Collagen quality.

\section{INTRODUCTION}

The boron compounds have been known for thousands of years. Boron is a non-metal element; it implies that its properties are intermediate between metallic and nonmetallic elements. This element is not present in nature in its elementary form, being the greatest boron source in the form of borates on sedimentary rocks, coal, oceans and some grounds.

In the terrestrial cortex, boron concentrations reach $10 \mathrm{mg} / \mathrm{Kg}$ and 4,5 $\mathrm{mg} / \mathrm{L}$ in the ocean. This element is released into the environment by the natural meteorization of rocks, volatilization of boric acid from the sea water by geothermal activity, and to a lesser extent from anthropogenic activities (IPCS, 1998). The most important borate deposits are located in the USA, Argentina, Turkey, Chile, Russia, China and Peru, where total boron compounds production reached around 2.750.000 tons in 1994. Older registries mention that in the first half of XX century, Chile became the first worldwide borate producer, being the master depots located in Surire and Ascotan salt mines in the regions of Tarapaca and Antofagasta (Chong et al., 2000).

Within commercial products and the most important minerals that contain boron are the borax pentahydrate, sodium perborate, boric acid, colemanite and ulexite. Different applications for these compounds exist, between which can be mentioned: fiber glass, enamels, fire delayers, fertilizers and agricultural herbicides (IPCS, 1998).

Studies indicate that boron ingestion by human beings is $0.44 \mu \mathrm{g} /$ day from the environment, $0.2-0.6 \mathrm{mg} /$ day in the drinking water and of $1.2 \mathrm{mg} /$ day in the feeding (IPCS, 1998), while the maximum boron concentration in drinking water according to the WHO is of $0.6-1 \mathrm{mg} / \mathrm{L}$. Irrigation water is 
one of the main sources of high boron concentrations that cause toxicity in rural zones. In Chile, there is information from the XV region, in the city of Arica, where the potable water is obtained from underground napas of the valley of Azapa, and by demographic necessities the underground and saline waters from the valley of Lluta had to be used to obtain potable water for the new populations of the North sector of the city. These waters of different nature from those from Azapa are influenced by a different geochemical system, where the average concentrations of boron in these waters are of $6.92 \mathrm{mg} / \mathrm{L}$ for the Northern sector and $1.98 \mathrm{mg} / \mathrm{L}$ for the Southern sector of the city (Luque, 2005), being the limits of boron concentration in this city 6 and $15 \mathrm{mg} / \mathrm{L}$ (Espinoza et al., 2005).

The studies demonstrate that high boron concentrations (with levels 100 to 1000 times greater than the levels of normal exposure) produce chronic toxicity in animals, which prevents the normal development of their reproduction by altering gametogenesis (IPCS, 1998). Boron was determined as non-classifiable regarding its carcinogenicity in humans (Luque).

Boric acid has been related in studies as the cause of abnormalities in the development of laboratory animals, being the pregnant rat the most sensitive of these organisms. In order to extrapolate these results to humans it is essential to consider the pharmacokinetic and pharmacodinamic differences between pregnant rats and pregnant women. The pharmacokinetics of boric acid is similar in rats and humans with respect to absorption, distribution and metabolism (Vaziri et al., 2001).

On the other hand, an extensive bibliography related to experimental studies with boric acid does exist, about its poisonous effects and the morphologic and/or functional changes, especially in laboratory animals reproductive organs. In spite of this, little information exists about the effects that it would specifically have in the liver tissue of laboratory rats, and -considering the information that these results could give about humans- this particular study acquires a special relevance.

Liver. While the liver develops, its cells gradually acquire the capacity to perform the proper functions of a functionally mature liver (Carlson, 2000), like for example the detoxification of toxic substances such as drugs, pesticides, etc. (Espinoza et al., 2002).

The liver is the biggest gland of the body, receiving double blood irrigation, with oxygenated blood from the right and left hepatic arteries and nutrients-rich blood from the portal vein (Gartner \& Hiatt, 1997), being the first organ in receiving the metabolic substrates and nutrients from food. For this reason, the liver is exposed to toxic substances that are absorbed, degraded or conjugated (Espinoza et al., 2002).

Histological characteristics. The liver is surrounded by a thin connective tissue layer, the capsule of Glisson, which becomes thicker around the inferior cava vein and in hepatic hilium. The connective tissue divides the hepatic parenchyma in lobules and receives the name of periportal connective tissue, since it surrounds the portal triads. Within the lobule, a rigid network of reticular fibers is observed that in the periphery are continued by the interlobular periportal connective tissue.

The hepatocytes are polygonal cells, from 20 to 30 $\mu \mathrm{m}$ of diameter, that are packed to each other to form anastomosing plates of hepatic cells. They constitute $80 \%$ of the total of the cellular population of the liver. Their nuclei are big, spherical and of central position, with two or more nucleoli. Hepatocytes have a large lifespan and high regeneration capacity, mainly used when there are losses by hepatotoxic processes, diseases or surgeries.

Their distribution permits not only that each single cell makes contact with another, but also they border a space of Disse. The space of Disse is the perisinusoidal space, which is located between the sinusoidal wall and the hepatocyte. It is mainly occupied by the microvilli of the hepatocytes. In this space, the metabolic interchange between the hepatocytes and the plasma takes place.

Therefore, they would have lateral dominions and sinusoidal dominions. The lateral dominions form spaces called biliary canaliculii that conduct the bile between the hepatocytes towards the periphery of the lobules. Short microvilli are projected from the hepatocytes towards the biliary canaliculii, increasing the surface area by which bile is secreted. The sinusoidal dominions of the hepatocytes also have microvilli that project towards the space of Disse. These microvilli increase the surface area of the sinusoidal dominion, facilitating the interchange of materials between the hepatocyte and plasma in the perisinusoidal space (Gartner \& Hiatt).

Hepatocytes are distributed into hexagonal lobules, limited by partitions or interlobular divisions (Di Fiore, 2003). The site where three lobules make contact to each other is called portal areas (triads). The portal areas lodge thinner branches of the hepatic artery, portal veins and biliary conduits. The longitudinal axis of each lobule is occupied by the central vein, which has a very thin wall and is surrounded by a fine layer of connective tissue (Geneser, 1999). The hepatocytes are projected like the rays of a wheel 
from the central vein and to each other forming anastomosing fenestrated plates of hepatic cells separated by great vascular spaces called hepatic sinusoids (Gartner \& Hiatt).

In the hepatic sinusoids, blood flows from the triad area towards the central vein, and this blood cannot make contact with the hepatocytes by the presence of a layer of sinusoidal coating cells (Ham \& Cormack, 1988). The sinusoidal wall is made up of endothelial cells and macrophages called Küpfer cells, movable cells which via extensive phagocytosis avoid the possible obstruction of the sinusoids by debris of diverse type (Geneser).

Given that this space acts like an intermediary compartment, the hepatocytes do not enter into direct contact with blood (Gartner \& Hiatt).

The liver, as the place of arrival of many toxicants, maintains a continuous balance between proliferation and apoptosis. The apoptosis is a process of programmed cellular death, where the cell nucleus and cytoplasm shrink and the chromatin is disintegrated, being engulfed by local phagocytes and disappearing without no inflammatory response; in this case, the phagocytes are the Küpfer cells (Ganong, 1998) and this process of programmed cell death in the liver occurs as a normal stage during the development of this organ and, in the adult, during the regeneration and renovation of hepatocytes (Espinoza et al., 2002).

Hepatocytes have a great replication capacity and are able to repopulate the liver quickly. However, this capacity can be blocked or delayed by different factors like liver diseases or poisonings (Espinoza et al., 2002). In cases of prolonged and constant loss of hepatocytes without the corresponding compensatory proliferation, for example in alcoholism, connective tissue is formed leading to fibrosis, and this one gradually is transformed into hepatic cirrhosis (Geneser).

Summarizing, the characteristics of boron poisoning turn out to be very harmful for the organism since they have been demonstrated in numerous investigations. Nevertheless, little information exists about its effects in the hepatic tissue of mice. If we consider that the liver is an organ where toxic substances are treated, determining and knowing about the effects that this nonmetal can exert on the hepatic tissue is fundamental since from its function depends the general balance of the organism. And even more if we consider that a great part of the population of Arica ingests daily important amounts of boron through the potable water.

Therefore, the hypothesis of this work was that boron consumption in high concentrations would produce alterations in hepatocytes, increase of the amount of binucleated hepatocytes, redistribution of glycogen and components of the connective tissue (collagen fibers) as reaction of the organ to boron toxicity.

\section{MATERIAL AND METHOD}

Biological: Animals: 63 mice (Mus musculus), CF1 strain, were obtained from the animal room of the Laboratory of Biology of Reproduction of the Medical School (Universidad de Chile), maintained under conditions of $12 \mathrm{~h}$ light: $12 \mathrm{~h}$ dark, at a temperature of $22^{\circ} \mathrm{C}$ and fed with commercial pellet and water ad libitum.

METHODS. Experimental design:The animals were randomly separated into three experimental groups, plus three control groups:

1. The first experimental group (E1) was made up of 10 mice of 8 days of age.

2. The second experimental group (E2) was made up of 12 mice of 126 days of age.

3. The third experimental group (E3) was made up of 10 mice of 126 days of age.

4. The control group 1 (C1) was made up of 10 mice of 8 days of age.

5. The control group 2 (C2) was made up of 11 mice of 126 days of age.

6. The control group 3 (C3) was made up of 10 mice of 126 days of age.

Preparation of the drinking water with boron: It was prepared with tap water of Santiago (which presents a boron concentration of $0.6 \mathrm{mg} / \mathrm{L}$ ) on a dose of $12 \mathrm{mg}$ boron/L; therefore, we dissolved $0.0686 \mathrm{~g}$ of boric acid to obtain a final boron concentration within the ranks that are consumed in Arica, which are between $6-12 \mathrm{mg} / \mathrm{L}$ (Espinoza et al., 2005).

\section{Treatments:}

1. The E1 group received boron during their period of gestation, via transplacentary route, and during lactation via maternal milk.

2. The E2 group received drinking water containing boron during a period of 42 days, beginning on day 84 of age.

3. The E3 group received drinking water containing boron during a period of 49 days, beginning on day 77 of age.

4. Control groups received drinking water of Santiago $(0,6$ $\mathrm{mg} \mathrm{B} / \mathrm{L})$.

After receiving boron-containing drinking water during the predetermined period, mice were sacrificed by 
ether vapors overdose (method approved by the Bioethics Committee of Universidad de Chile). After sacrifice, their livers were surgically removed from the abdominal zone. Once extracted, the liver was fixed with an aqueous Bouin solution and then transferred to ethanol $70 \%$, previous to embedding of the samples into paraffin blocks.

Histological techniques: For the histological evaluation of the diverse hepatic structures, the liver was fixed with an aqueous Bouin solution, passed through a battery of alcohols of ascending concentration and xylol, and embedded into paraffin at $60^{\circ} \mathrm{C}$. Then, $5-7-\mu \mathrm{m}$ sections were obtained.

For the counting of binucleated cells, serial sections were made, collecting the tenth section of each series. Two tissue samples were prepared per animal, mounting three liver sections per slide, stained with hematoxylin-eosin $(\mathrm{H}-$ E). Two hundred cells per animal were observed under light microscopy with the 100x objective lens and immersion oil. This procedure was performed in the same way for all the groups.

Determination of the staining level of liver glycogen in hepatic lobules: an assembly of four liver sections per slide was carried out corresponding to different animals from a same group and stained with PAS-hematoxylin. The determination of the degree of cytoplasmic coloration of the glycogen was made in the same way for all the groups. As the limits of the lobule in mouse liver are not well determined, a lobule was defined as a 10-cell radius from the central vein towards its periphery, thus having a uniform area for analysis, in where 10 hepatic lobules per animal were observed. The slides were observed through a light microscope using the $40 x$ objective.

The tissue intensity of reaction to the stain was defined by the following scale:

a) $\mathrm{X}=$ slight reaction.

b) $\mathrm{XX}=$ moderate reaction.

c) $\mathrm{XXX}=$ intense reaction.

Determination of the staining level of collagen fibers of the hepatic connective tissue: an assembly of four liver sections per slide was carried out corresponding to different animals from a same group and stained by the Mallory method. The determination of the degree of collagen staining was made in the same way for all the groups. The observed hepatic areas were 10 triad areas and 10 central veins per mouse. The slides were observed with a light microscope, using the 40x objective lens.

The tissue intensity of reaction to the stain was defined by the following scale: a) $\mathrm{X}=$ slight reaction.

b) $\mathrm{XX}=$ moderate reaction.

c) $\mathrm{XXX}=$ intense reaction

Additionally collagen was analyzed by polarized light microscopy based on the birefringence of the different types of fibres as revealed by the Picrosirius red method (Junqueira et al., 1978; Junqueira et al., 1979).

Statistical Analysis. The non-parametric Mann-Whitney test and the Chi-Square (X2) test of independence were used.

\section{RESULTS}

The initial step for analyzing the samples for the collection of results consisted in the evaluation of the histological sections of hepatic tissue of mice (CF-1 strain) exposed to boron during periods of time of 8,42 and 49 days according to the group they belonged, with a preestablished dose of $12 \mathrm{mg}$ of boron in drinking water. At the same time, histological tissue sections from mice that did not receive boron, the control groups, were evaluated. A comparison between the control groups $\mathrm{C} 2$ and $\mathrm{C} 3$ was carried out, revealing no significant differences. Thus, we reunite the data of both groups into a single control (C2-3). The same happened with the experimental groups E2 and E3 (E2-3).

The analysis begins with the microscopical observation of the slides to count the binucleated cells from 200 hepatocytes per mouse. Variations in the amount of these cells in the different experimental groups were noticed in comparison to the controls that only received tap water from Santiago city. For this analysis we used the non-parametric test of Mann-Whitney, considering $\mathrm{p} \leq 0.05$ as the critical value for statistical significance. For the analysis of groups $\mathrm{C} 1$ and E1, we analyzed 10 sections in each case resulting an average of binucleated cells relative to 200 hepatocytes of 22.9 and 28.5 (see Table I); the standard deviation of the groups reached 6.7 in $\mathrm{C} 1$ and 6.8 in E1, which shows that data distribution in both groups oscillated in the same way. In relation to the Mann-Whitney test, the result threw a p> 0,05 , showing no significance difference between both groups of data. The difference that the E1 group shows respective to the control cannot be attributed to boron ingestion, but to any other external factor or simply to hazard.

The analysis of binucleated cells continued in the groups of mice with boron ingestion during 42 and 49 days. The C2-3 group threw an average of 43.9 binucleated cells per each 200 hepatocytes; however, the E2-3 group turned 
out to have an average of 76 binucleated cells per each 200 hepatocytes. Like $\mathrm{C} 1$ and $\mathrm{E} 1$, the oscillation of the data that threw C2-3 and E2-3 is similar between both, although higher than the other groups. These results were obtained from samples conformed by 21 mice, in the case of the group C23 , and 22 mice, in the case of the E2-3 group (see Table II). Regarding the Mann-Whitney test for the results of C2-3 and E2-3, the p-value between these groups turned out to be smaller than 0.01, which statistically means highly significant. This implies that the distribution of the data of both groups establishes a highly significant difference. It is possible to speculate that a high probability exists that boron ingestion during 42 and 49 days in the adult mouse might be related to a significant increase in the number of hepatic binucleated cells.

Table I. Group 1. Mean, Standard deviation (SD) and Standard Error for the amount of binucleated cells per 200 hepatocytes in both groups. Treatment during gestation and lactation.

\begin{tabular}{ccc} 
& C1 & E1 \\
\hline Mean & 22,9 & 28,5 \\
SD & 6,7 & 6,8 \\
$\mathrm{~N}$ & 10,0 & 10,0 \\
SE & 2,1 & 2,1
\end{tabular}

$\cdot$ Value $\mathrm{p}>0,05$ considered non-significant.

Table II. Groups 2-3. Mean, Standard deviation (SD) and Standard Error for the amount of binucleated cells per 200 hepatocytes in both groups, by $42-49$ days of treatment.

\begin{tabular}{ccc} 
& C2-3 & E2-3 \\
\hline Mean & 43,9 & 76,0 \\
SD & 12,5 & 12,4 \\
N & 21,0 & 22,0 \\
SE & 2,7 & 2,6
\end{tabular}

- Value $\mathrm{p}<0,01$ considered non-significant

Liver sections were submitted to a specific staining (PAS-hematoxyline) to visualize the levels of glycogen in hepatic lobules. For this study, the staining intensity was subdivided into slight, moderate and high. The results were analyzed with a Chi-square test of independence with the purpose of detecting differences in the distribution of data of the experimental and control groups. The total number of collected data of the $\mathrm{C} 1$ sample was 100 , the same as in the E1 group. The percentage distribution for the intensity of staining of hepatic glycogen in hepatic lobules in $\mathrm{C} 1$ was $45 \%$ slight, $42 \%$ moderate and $13 \%$ intense, while in E1 was $63 \%$ slight, $35 \%$ moderate and $2 \%$ intense (see Table III).
Table III. Percentage distribution for the intensity of staining of hepatic glycogen in hepatic lobules in $\mathrm{C} 1$ and E1. Treatment during gestation and lactation.

\begin{tabular}{cccc} 
& Slight & Moderate & Intense \\
\hline C1 & $45 \%$ & $42 \%$ & $13 \%$ \\
E1 & $63 \%$ & $35 \%$ & $2 \%$
\end{tabular}

According to the Chi-Square test for both groups, the p-value was 0.002 , lower than the level of significance established for this test $(0,05)$. This p-value allows inferring that the existing difference between the distribution of the data of $\mathrm{C} 1$ and $\mathrm{E} 1$ could be influenced by boron. This difference is given by an increase of the level of slight staining in the E1 group and a diminution in the other two levels. On the other hand, the total number of collected data of the C2-3 was of 210 samples and in the E2-3 group it was a total of 220 samples. The percentage distribution of the staining level of the glycogen present in hepatic lobules in C2-3 was 24\% slight, $43 \%$ moderate and $33 \%$ intense, while in E2-3 was 50\% slight, $44 \%$ moderate and $6 \%$ intense (see Table IV).

Table IV. Percentage distribution for the intensity of staining of hepatic glycogen in hepatic lobules in C2-3 and E2-3, by 42-49 days of treatment.

\begin{tabular}{cccc} 
& Slight & Moderate & Intense \\
C2-3 & $24 \%$ & $43 \%$ & $33 \%$ \\
E2-3 & $50 \%$ & $44 \%$ & $6 \%$ \\
\hline
\end{tabular}

Concerning the Chi-Square test of independence for both groups the p-value turned out to be smaller than 0.001 , which is lower than the level of significance established for this test $(0,05)$. This $p$-value allows inferring that the existing difference between the distribution of the data of C2-3 and E2-3 could be influenced by boron. This difference was given by an increase of the level of the slight intensity in the E2-3 group and a diminution in the other two levels.

The following analysis corresponds to the observation of the level of staining of collagen. This was focused in two zones of the hepatic tissue where these fibers are located in greater amount. These were around the central vein and the triad area. For both zones a total of 200 areas divided in equal parts for the group $\mathrm{C} 1$ and $\mathrm{E} 1$. These data were obtained from a sample of 10 mice by group. The number of zones around the central vein where collagen staining was observed as slight staining was $34 \%$, increasing to moderate level up to $54 \%$ and diminishing to high level in 12 . On the other hand, for the E1 group the percentage of the level of intensity of collagen staining around the central vein was 86 as slight level, 14 as moderate level and 0 for the high livel (see table V). 
Table V. Percentage distribution for the level of staining of collagen around the central vein in $\mathrm{C} 1$ and $\mathrm{E} 1$. Treatment during gestation and lactation.

\begin{tabular}{cccc} 
& Slight & Moderate & Intense \\
\hline C1 & $34 \%$ & $54 \%$ & $12 \%$ \\
E1 & $86 \%$ & $14 \%$ & $0 \%$
\end{tabular}

In order to clarify the degree of significance of the difference between $\mathrm{C} 1$ and $\mathrm{E} 1$, the test of independence of Chi-Square was applied, revealing that results of both groups differ with a p-value lower than 0,001 . This difference is based fundamentally on the diminished moderate and high levels of staining of $\mathrm{E} 1$ in relation to the $\mathrm{C} 1$ group, despite the increment in the slight level. The analysis in the triad area for these groups revealed that the staining level was distributed in the following way: in C1, 3\% slight level, 58\% moderate level and 39\% for the intense level. In E1, 62\% slight level, 33\% moderate level and 5\% intense level (see Table VI).

Table VI. Percentage distribution for the level of staining of collagen in triad areas in $\mathrm{C} 1$ and E1. Treatment during gestation and lactation.

\begin{tabular}{cccc} 
& Slight & Moderate & Intense \\
\hline C1 & $34 \%$ & $54 \%$ & $12 \%$ \\
E1 & $86 \%$ & $14 \%$ & $0 \%$
\end{tabular}

Similar to our findings in the central vein, the distribution of the data for the level of staining in the portal triad between both groups differs significantly since the pvalue for the Chi-Square test is lower than 0,001. Statistically, there are reasons to consider that boron can play an important role in the presence of collagen in the periphery of the central vein as well as in the portal triad.

Continuing with the analysis of the level of staining, the sample number for the C2-3 group was of 210 and for the E2-3 group was of 220. These data were obtained from a sample of 11 mice for the C2-3 group and 12 mice for the E2-3 group. In the C2-3 group, the number of zones around a central vein where the collagen staining was observed in a slight level was 39\%, 53\% in a moderate level and $8 \%$ at intense level. On the other hand, for the E2-3 group the percentage of slight staining was $55,40 \%$ in the moderate level and 5\% in the intense level (see Table VII).

As in groups $\mathrm{C} 1$ and E1, in the groups C2-3 and E23 the statistical difference is significant, since the p-value for the Chi-square test equals to 0,002. Therefore, it can be inferred that the observed differences can be influenced by boron. The analysis in the portal triad for these groups indicated that the staining level was distributed as follows: in C2-3, 8\% slight level, 57\% moderate level and 35\% intense level. However in E2-3, 31\% slight level, 53\% moderate level and $16 \%$ intense level (see Table VIII).

Table VII. Percentage distribution for the level of staining of collagen in triad areas in C2-3 and E2-3.

\begin{tabular}{cccc} 
& Slight & Moderate & Intense \\
\hline C2-3 & $39 \%$ & $53 \%$ & $8 \%$ \\
E2-3 & $55 \%$ & $40 \%$ & $5 \%$
\end{tabular}

Table VIII. Percentage distribution for the level of staining of collagen in portal triads in C2-3 and E2-3.

\begin{tabular}{cccc} 
& Slight & Moderate & Intense \\
$\mathrm{C} 2-3$ & $8 \%$ & $57 \%$ & $35 \%$ \\
$\mathrm{E} 2-3$ & $31 \%$ & $53 \%$ & $16 \%$ \\
\hline
\end{tabular}

Similar to the findings around the central vein, the distribution of the data for the level of staining the portal triad between both analyzed groups differed significantly since the p-value for the Chi-square test is lower than 0,001. Therefore, it can be stated statistically that it is due to the effect of boron exposure.

The Picrosirius red technique for evaluation of the presence and type of collagen in the liver as well as differences in their expression in control and boron treated mice was performed. Thus, predominance of gross fibers, collagen type I, (red-orange refringence) shifted to thin fibers (reticulin), type III-collagen, of white-greenish color under polarized light. This change was found chiefly at the portal triads, been also visible in some cases at the periphery of the central vein (Figs. 1 and 2).

\section{DISCUSSION}

In experiments made in male rats by $\mathrm{Ku} \&$ Chapin (1994), boron poisonous effects are demonstrated at the testicular level, starting with the inhibition of spermiation and epithelial disorganization of the seminiferous tubules, finishing in testicular atrophy. No information exists about boron effects on the hepatic tissue. Therefore, it is urgent to carry out investigations on the possible poisonous effects of this nonmetal on the liver. In order to extrapolate these results to humans, it is essential to consider the pharmacokinetical and pharmacodynamical differences between humans and the animal model. In the case of boric acid, its absorption, distribution and metabolism are similar between rats and humans according to studies made by Nosratola et al. 


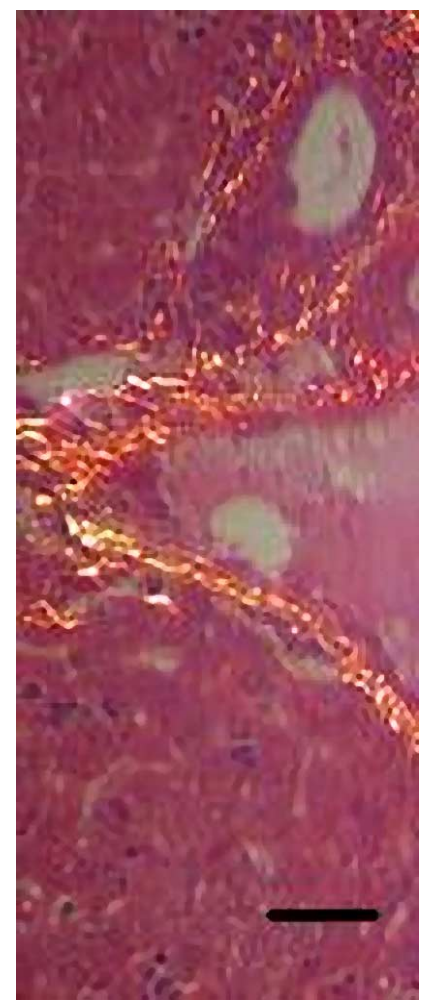

Fig.1 Liver section (control animal) stained with Picrosirius red and examined under polarization microscopy. Portal triad showing predominant yellow-reddish birefringence (Collagen type-I) (bar: $10 \mu \mathrm{m})$.

In relation to hepatocytes and the continuous balance between the processes of proliferation and apoptosis, it is possible to state that the balance and the maintenance of the cellular types is necessary for the correct function of the organ. Espinoza et al. (2002), in a study of the effects of Parathion (PT) on the apoptosis index in CF1 mice hepatocytes, indicate that this dynamic balance can be altered by internal or external factors. They establish that both the number of binucleated cells and the apoptosis index increases significantly after the first 24 hours after treatment with PT. Also, it was observed that in adult mice which consumed boron during 42 and 49 days the amount of cells in mitosis doubles its number. These results are significantly far away from the normal process of endomitosis and apoptosis that happens constantly in the liver. For Espinoza et al. (2002), the increase in binucleated cells may be due to the lipophylic characteristics of PT that alter the permeability of the cell membranes of the hepatocytes. In addition, another factor that would be responsible for the increase of the apoptosis is the inhibitory properties of PT over the activity of the enzyme acetylcholinesterase that causes blood vessels constriction, thus reducing the blood flow in the liver. A different case is that of mice that consumed boron during gestation and lactation. In them, a slight increase in the binucleated cell number can be noticed but it does not differ with the process that occurs normally in the liver. In a study of pregnant rats with copper ion, Acuña et al. (1999) observed important accumulations of this metal in the liver of the fetus,

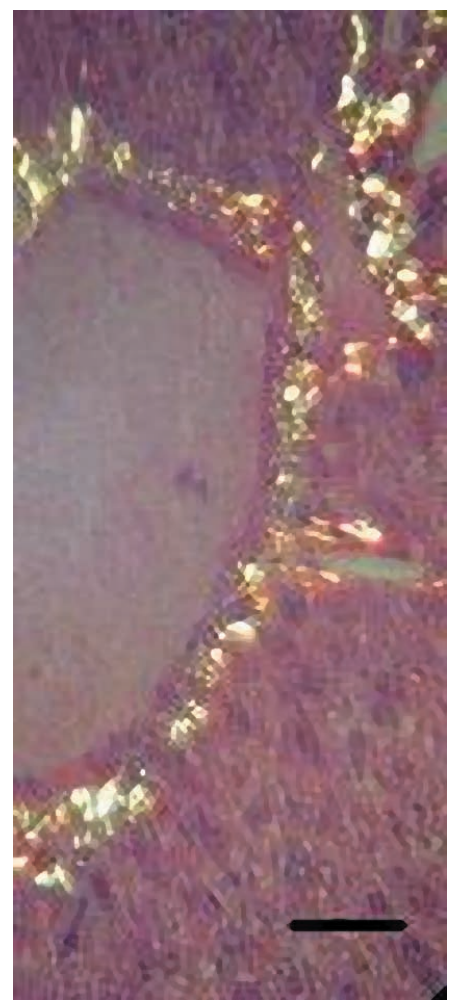

Fig. 2 Liver section (boron treated animal) stained with Picrosirius red and examined under polarization microscopy. Around the periphery of the hepatic artery and of the portal vein (upper right angle), whitegreenish birefringence is predominant with a minor component of yellow-reddish color denoting predominance of collagen type-III over collagen type-I (bar: $10 \mu \mathrm{m}$ ). revealing that this ion is able to trespass the placenta and arrive to the hepatic tissue. This would not be the case of boron, according to the results of Moseman (1994) which stated that boron apparently is not accumulative in animal tissues. Nevertheless, we could not deny that boron alters the function of the hepatocyte glycogen storage and the supportive function of collagen. The few results obtained respect to boron do not allow us to understand the lack of increase of binucleated cells in the E1 group, needing complementary studies.

Another related study is the one of González et al. (2004) who, when observing the effects of ethanol on the liver of adolescent rats, indicated among other things that hepatocytes in the perivenous zones of the hepatic lobule are diminished in size, with nuclei that appear heterochromatic and some with marginalization of chromatin, morphological characteristics of cells described by other authors as apoptotic cells. They also state that the cellular death by necrosis causes massive damage causing the collapse of the internal homeostasis of the cells with loss of the synthesis of ATP, the integrity of the cell membrane and the expression of genes (González, 2003). In the present study, boron could have caused all this collapse.

Boron probably influences one of the main functions of the hepatocytes, specially over the metabolism and storage of glycogen. In the study of González et al. (2003) in 
alcoholic rats, glycogen was seen very diminished and forming small areas in the perivenous zone, in the intermediate zone as well as in periportal zones. Alike the present study, it was observed that the staining of glycogen tends to increase in its slight intensity and to diminish in its moderate or intense reaction.

The third point relates to collagen. We lack information relative to boron action on these fibers. Without a doubt they posses an essential rol, since they are the most abundant component of the connective tissue, while at the same time provide it with strength and flexibility (Geneser). There are no differences in the results of the groups analyzed in this investigation on this parameter, i.e., in each experimental group there was only a minor increase in the slight intensity level of the staining for collagen in comparison to the control groups whilst the other two diminished. This diminution of the collagen, or its thinning, could have important consequences in the consistency and resistance of the hepatic tissue. These data are opposed to investigations like those of Castilla (1993) that indicates that in hepatic diseases like cirrhosis and viral hepatitis, an increase of the collagen can be seen given by an increase on its synthesis or a diminution on its degradation and thus generating extensive areas of fibrosis. The toxic effect of boron occurs beyond the function of the hepatocytes, altering the production of collagen on the part of the cells of Ito, the fibroblasts and endothelial cells.

Fail et al. (1998), emphasize that few studies exist on the chronic effects of boron in humans and a similar number in experimental animals, most of which are focused on its reproductive and developmental effects. The most documented reproductive damage corresponds to alterations of the spermatogenesis and degeneration of the seminiferous epithelium, indicating the necessity to extend the study of the toxicity of boron to other tissues.

In organs of many different species when stained by Picrosirius red and studied with polarization microscopy, different colors are seen in regions where collagens I, II and III have been described. Collagen I presented a yellow, orange or red color while collagen type-III appears green (Junqueira et al., 1978). A biochemical analysis of polarization colors of various purified collagens were studied in fibers of similar thickness. Picrosirius red staining and polarization microscopy was used for thin fibers $(0.8$ $\mu \mathrm{m}$ or less) and thick fibers (1.6-2.4 $\mu \mathrm{m})$. Most thin fibers show green to yellowish polarization color. Thick fibers show green to greenish yellow polarization colors while all other collagens show polarization color of longer wavelengths. Therefore, fiber thickness is not the only factor involved in determining polarization colors. Packing of collagen molecules results in reddish stained collagen (Dayan et al., 1989).

In the present work Picrosirius red staining shows differential staining under polarized light, been reddish color (collagen type I) predominant in controls that shifts to white-greenish (collagen type III) in boron treated tissues. Some reports correlate the decrease in collagen I and increase in type III after tissue injuries, followed by fibrosis (Shahzeidi et al.,1993; Ala-Kokko et al., 1987).

In the evolution of hepatic granuloma experimentally produced by schistosomiasis in mice two different types of collagen fibers appear successively, first thin weakly birefringent greenish fibers that are replaced by thicker collagen fibers displaying a stronger yellow-red birefringence. This results show a progressive organization of the collagenous scaffolding of hepatic granulomas, related to the age of the lesion (Andrade et al., 1999).

The opposite collagenous evolution occurs (as in our observations) when collagenolysis takes places, as it has been reported in the vaginal wall in cases of vesical prolapses (Borges et al., 2007).

The proportion of different birefringence colors of collagen fibers in normal and pathological tissues under polarization microscopy using Picrosirius red staining is an excellent method to assess fibers hue (Rich \& Whittaker, 2005).

Therefore, this methodology is highly informative about the mechanical and architectural features of the collagen spatial distribution in control and toxic exposed tissues, as found as boron damaging effect in mouse liver.

\section{CONCLUSION}

Boron, at hepatic level, produces an increase of binucleated cells as an attempt to restore the interrupted equilibrium after an elevation of the apoptosis of the hepatocytes is induced by the chemical element. On the other hand, the hepatic functions of storage and glucose metabolism are seriously altered after boron exposure, demonstrated by a considerable diminution of glycogen storage in the liver. Finally, boron has an impact in the consistency of the hepatic connective tissue since collagen deposits are diminished after exposure to the metalloid, shifting part of collagen type I to collagen type III, a finding that in other tissues has been reported to imply collagenolysis and a consequent weakening of the supporting role of collagen architecture. 
BUSTOS-OBREGÓN, E.; HARTLEY, B. R. \& CATRIA-GÁLVEZ, R. Efectos histopatológicos del boro en el hígado de ratón. Int. J. Morphol., 26(1):155-164, 2008.

RESUMEN: El boro es un elemento metaloide que se encuentra presente en la naturaleza en forma de boratos en rocas sedimentarias, carbón, océanos y algunos suelos. En nuestro país se encuentra en altas concentraciones en el agua potable de la XV región, en la ciudad de Arica, superando el límite máximo recomendado por la OMS. Se evaluó el efecto del boro, en una dosis de 12 mg/ L de agua (equivalente $0,0686 \mathrm{G}$ de ac. bórico) administrado por vía oral durante 8, 42 y 49 días a 3 grupos experimentales (10 animales cada uno). Cortes de hígado se tiñieron con Hematoxilina-eosina (células binucleadas), PAS hematoxilina (glicógeno hepático), Mallory y Rojo Picrosirius (fibras de colágeno). El boro produce diversos efectos en el hígado. Para el estudio de células binucleadas se utilizó el test no paramétrico de Mann-Whitney. El grupo C1 tuvo 22,9 células binucleadas cada 200 hepatocitos, en cambio E1 mostró 28,5 (p> 0,05) el análisis no arrojó una diferencia estadísticamente significativa entre ambos grupos. Grupo C2-3 mostró 43,9 células binucleadas cada 200 hepatocitos, por su parte E2-3 76 (p menor a 0,01) en este caso sí existe diferencia significa entre ambos grupos. La tinción de PAS fue clasificada como leve, moderada e intensa y su análisis realizado mediante Chi- Cuadrado. Todos los grupos controles y experimentales arrojaron diferencias significativas $(\mathrm{p}<0,01)$. La tinción de Mallory fue examinada en: triadas portales $(\mathrm{TrP})$ y venas centrales (VC). En ambas hubo incremento significativo. La tinción con Rojo Picrosirius analizada por microscopía de polarización, demostró que el colágeno III predomina en los animales tratados con boro, indicando colagenolisis de colágeno I como efecto tóxico del boro. En conclusión, el boro altera la distribución del glicógeno, la calidad del colágeno y el depósito de ambos en las dos áreas examinadas, en tanto que la cantidad de células binucleadas se comportan de forma distinta en los animales jóvenes respecto a los adultos.

PALABRAS CLAVE: Boro; Hígado de ratón; Contenido de glicógeno; Calidad del colágeno.

\section{REFERENCES}

Acuña, O.; Silva, T. G.; Lemus, A. D.; Fuenzalida, B. M.; Román, S. D.Rivera, Y. L. \& Varela, V. H. Intoxicación con ion cobre en ratas preñadas y su efecto en la formación de centros primarios de osificación en fetos. Rev. Chil. Anat., 17(2):217-24, 1999.

Ala-Kokko, L.; Pihlajaniemi, T.; Myers, J.C.; Kivirikko, K.I. and Savolainen, E.R. Gene expression of type I, III and IV collagens in hepatic fibrosis induced by dimethylnitrosamine in the rat. Biochem. J., 244(1):7579, 1987.

Andrade, G. B.; Montes, G. S.; Conceição, G. M. \& Saldiva, P. H. Use of the Picrosirius-polarization method to age fibrotic lesions in the hepatic granulomas produced in experimental murine schistosomiasis. Ann.Trop. Med. Parasitol., 93(3):265-72,1999.

Borges, L. F.; Gutierrez, P. S.; Marana, H. R. \& Taboga, S.R. Picrosirius-polarization staining method as an efficient histopathological tool for collagenolysis detection in vesical prolapse lesions. Micron., 38(6):5803, 2007.

Carlson, B. Embriología Humana y Biología del desarrollo. Second Edition. Elsevier, Amsterdam, 2000. Chapter 14, 335-40.

Castilla, A. Factores de crecimiento en la patogenia de la cirrosis hepática. Medicina Clínica; 100(18):702-704, 1993.
Chong, G.; Pueyo, J. \& Demergasso, C. Los yacimientos de boratos de Chile. Rev. Geol. Chile. 27(1):99-119, 2000.

Dayan, D.; Hiss, Y.; Hirshberg, A.; Bubis, J. J. \& Wolman, M. Are the polarization colors of Picrosirius red-stained collagen determined only by the diameter of the fibers? Histochemistry, 93(1):27-9, 1989.

Di Fiore, M. Atlas de Histología Normal. $7^{\text {th }}$ ed. El Ateneo, Buenos Aires, 2003. pp.126-131.

Espinoza, O.; Bustos-Obregón, E. \& Suja, J. A. Efecto del Parathion sobre el índice de apoptosis en hepatocitos de ratones CF1. Rev. Chil. Anat., 20(1):29-36, 2002.

Espinoza, O.; Vilaxa, A.; Rojas, S.; Granifo, L.; Histological study on the male reproductive organs of mouse CF1 treated with boric acid. Histology and Histopathology Cellular and Molecular Biology. First International Congress of Histology and Tissue Engineering; Supplement 1; Universidad de Alcalá, Spain, 2005.

Fail, P.; Chapin, R. E.; Price, C. J. \& Heindel, J. J. General, reproductive, developmental, and endocrine toxicity of boronated compounds. Reprod. Toxicol., 12(1):1-18, 1998.

Ganong, W. Fisiología médica. $60^{\text {th }}$ ed. Ed. Manual Moderno, México, 1998. Chapter 1 and 26; 29-30, 557-64, 603, 692-3. 
Gartner, L. \& Hiatt, J. Histología Texto y Atlas. Ed. McGraw Hill Interamericana. México, 1997. Chapter 18, 366-76,

Geneser, F. Histología. 3th ed. Ed. Médica Panamericana, Buenos Aires, 1999. Chapter 8 and 18; 197-203, 518531 ,

González, M.; Herrera, A.; Domínguez, C.; Coro, R. \& Lebredo, I. Efectos del alcoholismo crónico sobre las características morfológicas y ultramicroscópicas del hígado de ratas adolescentes. Sexto Congreso Virtual Latinoamericano de Anatomía Patológica. March, 1-31, 2004.

Ham, A.W. \& Cormack, D. H. Ham`s Histology. $9^{\text {th }}$ ed. Philadelphia. Lippincott, Chapter 19, 641-661, 1988.

International Programme on Chemical Safety (IPCS). Consenso Científico sobre el Boro. www.grenfacts.org/es/ boro; 1998 (downloaded June 1st, 2006)

International Programme on Chemical Safety (IPCS). Organización Mundial de la Salud. Environmental health Criteria 204 Boron. World Health Organization, 192-201, Geneva, 1998.

Junqueira, L. C.; Cossermelli, W. \& Brentani, R. Differential staining of collagens type I, II and III by Sirius Red and polarization microscopy. Arch. Histol. Jpn., 41(3):26774, 1978

Junqueira, L. C.; Bignolas, G. \& Brentani, R. R. Picrosirius staining plus polarization microscopy, a specific method for collagen detection in tissue sections. Histochem. Jour., 11(4):447-55, 1979.

Ku, W. W. \& Chapin, R.E. The Reproductive Toxicity of Boric Acid. Health Effects of Boron. Environmental Health Perspective, 102(7):87-91, 1994.

López, M. L.; Leyton, C. \& Graf, M. E.; Técnicas de Histología y Citología. $2^{\mathrm{a}}$ ed. Departamento de Biología Celular y Genética. Facultad de Medicina. University of Chile, Santiago. 141, 1982.

Luque, A. Cambios inducidos por el boro en el dimorfismo sexual de Drosophila melanogaster. Thesis (Lic. in Biological Sciences). University of Tarapaca. Arica, Chile. 2005.

Moseman, R. Chemical disposition of boron in animals and humans. Enviromental Health Perspective; 102 (7):1137, 1994.
Rich, L. \& Whittaker, P. Collagen and Picrosirius red staining: a polarized light assesement of fibrillar hue and spatial distribution. Braz. J. morphol. Sci. 22(2):97-104, 2005.

Shahzeidi, S.; Mulier, B.; Crombrugghe, B.; Jeffery, P. K.; McAnulty, R. J. \& Laurent, G. J. Enhanced type III collagen gene expression during bleomycin induced lung fibrosis. Thorax. 48:622-8,1993.

Vaziri, N. D.; Oveisi, F.; Culver, B. D.; Pahl, M.V.; Andersen, M. E.; Strong, P. L. \& Murray, F. J. Effect of Pregnancy on Boron Renal Clearance in Sprague-Dawley Rats Given Boric Acid Orally. Toxicological Sciences, 60:25763, 2001 .

Correspondence to:

Prof. Dr. Eduardo Bustos-Obregón

Laboratory of Biology of Reproduction. ICBM.

Medical School

Universidad de Chile

Av. Independencia 1027

P.O.Box 70061-7

Santiago 7

Santiago- CHILE

Phone. 56-2-9786473

Fax. 56-2-7373158

Email: ebustos@med.uchile.cl

Received: 23-09-2007

Accepted: 12-12-2007 